\title{
Efficient single-layer light-emitting diodes based on organic-inorganic lead halide perovskite and tuning luminescence properties
}

\author{
Soghra Mirershadi ${ }^{1,2} \cdot$ Asal Javad $^{3,4} \cdot$ Sohrab Ahmadi-Kandjani ${ }^{5}$
}

Received: 24 July 2018 / Accepted: 5 May 2019 / Published online: 11 May 2019

(c) The Author(s) 2019

\begin{abstract}
Because of the interesting features of the organic/inorganic halide perovskite (e.g., $\mathrm{CH}_{3} \mathrm{NH}_{3} \mathrm{~Pb} X_{3}, X=\mathrm{Cl}, \mathrm{Br}$ ) materials, such as long electron-hole diffusion length, high absorption coefficient and adjustable band gap, they have attracted a great deal of attention. In this research, $\mathrm{CH}_{3} \mathrm{NH}_{3} \mathrm{~Pb} X_{3}(X=\mathrm{Br}, \mathrm{Cl})$ are synthesized and perovskite-based single-layer and perovskite-based bilayer diodes are fabricated. Using electron beam deposition technique, thin films of $\mathrm{CH}_{3} \mathrm{NH}_{3} \mathrm{~Pb} X_{3}(X=\mathrm{Br}, \mathrm{Cl})$ hybrids with excellent homogeneity are manufactured. Absorption spectrum, $X$-ray spectrum and photoluminescence spectrum of organic/ inorganic halide perovskites along with electroluminescence spectra, SEM micrographs and current-voltage characteristic of perovskite-based light-emitting diodes are investigated. Perovskite-based bilayer diodes are evaluated for the first time. The difference between the emission wavelengths of single-layer and bilayer diodes is the main characteristic of bilayer diodes.
\end{abstract}

Keywords Perovskite light-emitting diode $\cdot$ Lead halide perovskite $\cdot$ Electroluminescence $\cdot$ Thin film

\section{Introduction}

Organic/inorganic halide perovskites (OIHPs), a new class of semiconductors, have shown huge potential for optoelectronic applications in the current decade, due to their long-range balanced hole-electron transport and high power conversion efficiency [1-5]. These interests originate from the high absorption coefficient, solution process capability, long exciton diffusion length, high exciton binding energy, tunable optical band gap from visible to infrared

Soghra Mirershadi

s.mirershadi@uma.ac.ir

1 Department of Engineering Sciences, Faculty of Advanced Technologies, University of Mohaghegh Ardabili, Ardabili, Namin, Iran

2 Department of Engineering Sciences, Faculty of Advanced Technologies, Sabalan University of Advanced Technologies (SUAT), Namin, Iran

3 School of Engineering-Emerging Technologies, University of Tabriz, Tabriz 51665-163, Iran

4 Department of Electrical Engineering, Science and Research Branch, Islamic Azad University, Tehran, Iran

5 Research Institute for Applied Physics and Astronomy, University of Tabriz, Tabriz 51665-163, Iran spectrums, low-cost and low-temperature processing of OIHPs $\left(\mathrm{CH}_{3} \mathrm{NH}_{3} \mathrm{~Pb} X_{3}, X=\mathrm{Br}, \mathrm{Cl}\right.$, I) [6-9].

On the other hand, OIHPs have displayed wonderful proficiency in solar cell usage and optical gain [10-14]. Also, they have superb photoluminescence (PL) properties, which make them suitable choice for creating perovskite light-emitting diode (PeLED), with adjustable near-infrared and visible spectrum [11, 15-17]. In addition to their ambipolar features, these kinds of materials have been confirmed to be electrically light emitter $[1,18]$. Very recently, a breakthrough in light-emitting diodes (LEDs) based on organic-inorganic halide perovskite has been made, which proves OIHPs as promising candidates in LEDs [1].

Even though numerous studies have been carried out on the use of perovskite structures in light-emitting diodes, the study of the electroluminescence properties of these structures, without the aid of electron and hole transmitter layers, is done, for the first time, in this study. This is due to the higher mobility of charge carriers in perovskite structures [19-24]. It has been shown that by sandwiching a perovskite layer between the organic hole layer and the electron blocking layer in perovskite-based light-emitting diodes, a narrow emission spectrum and a high quantum yield can be obtained [25]. By adjusting the halide blend in $\mathrm{CH}_{3} \mathrm{NH}_{3} \mathrm{~Pb} X_{3}$, PeLEDs can radiate from visible to nearinfrared region [26]. 
Recently, color-controlled electroluminescence (EL) devices like PeLEDs have been promised for future displays and lightening applications [27, 28]. As a result of their potential for generating less twisted display modules, good color quality and higher resolution of color tunability, PeLEDs have been under a spot light.

As reported elsewhere, the photoluminescence quantum efficiency (PLQE) of thin-film perovskites is above 20\%, under a low excitation intensity. Through intensifying the excitation density, the PLQE grows fast and reaches a maximum level of about 70\% $[29,30] . \mathrm{CH}_{3} \mathrm{NH}_{3} \mathrm{PbBr}_{3}$ perovskite have illustrated PLQEs of about 75\% [31].

Electroluminescence of perovskite films were also obtained at low temperatures, while incorporation of an organic emitter has yielded EL at room temperature as well $[32,33]$. Although several studies have been performed to explore the PL characterization of halide perovskites, there is a lack of report on stacked perovskite layers for tailoring of the emission spectra. Many reported PeLEDs have a multilayer device. In cases with the minimum layers, they have an electron injection layer (EIL) next to the cathode, to simplify electron injection into the emitting layer (EML), and a hole-injection layer (HIL) near the anode, in order to simplify hole injection into the EML and the perovskite emissive layer [28]. The brilliant point of our work is that we use nothing as a hole blocking layer or electron blocking layer.

Recently, we found that a single-layer PeLEDs can produce light with no EIL or HIL, through applying a thin film of $\mathrm{CH}_{3} \mathrm{NH}_{3} \mathrm{PbBr}_{3}$ perovskite and $\mathrm{CH}_{3} \mathrm{NH}_{3} \mathrm{PbCl}_{3}$ perovskite. In this research, we investigate PeLEDs with high spectral purity at room temperature. The device schematics are illustrated in Fig. 1, in which they show a thin layer of $\mathrm{CH}_{3} \mathrm{NH}_{3} \mathrm{PbBr}_{3}$ and $\mathrm{CH}_{3} \mathrm{NH}_{3} \mathrm{PbCl}_{3}$ perovskites, which are deposited via electron beam evaporation technique as an EML — on top of the ITO layer-and HIL, respectively. The PeLEDs were supplemented using Ag as the top electrode. (Devices A and B).

For PeLED, with double layers of perovskite (device C), shown in Fig. 1c, a thin layer of $\mathrm{CH}_{3} \mathrm{NH}_{3} \mathrm{PbCl}_{3}$ is coated on the ITO by electron beam evaporation technique. Then a thin layer of $\mathrm{CH}_{3} \mathrm{NH}_{3} \mathrm{PbBr}_{3}$ perovskite was evaporated through electron beam technique on the $\mathrm{CH}_{3} \mathrm{NH}_{3} \mathrm{PbCl}_{3}$ layer.

\section{Experimental}

\section{Preparation of materials}

Synthesis of $\mathrm{CH}_{3} \mathrm{NH}_{3} \mathrm{PbBr}_{3}$ perovskite: by adding $1.175 \mathrm{ml}$ of $40 \mathrm{wt} \%$ methylamine to $1.536 \mathrm{ml}$ of $47 \mathrm{wt} \%$ hydrobromic acid in to a $250 \mathrm{~mL}$ round-bottom flask, methylammonium bromide $\left(\mathrm{CH}_{3} \mathrm{NH}_{3} \mathrm{Br}\right)$ was made. The mixture blend
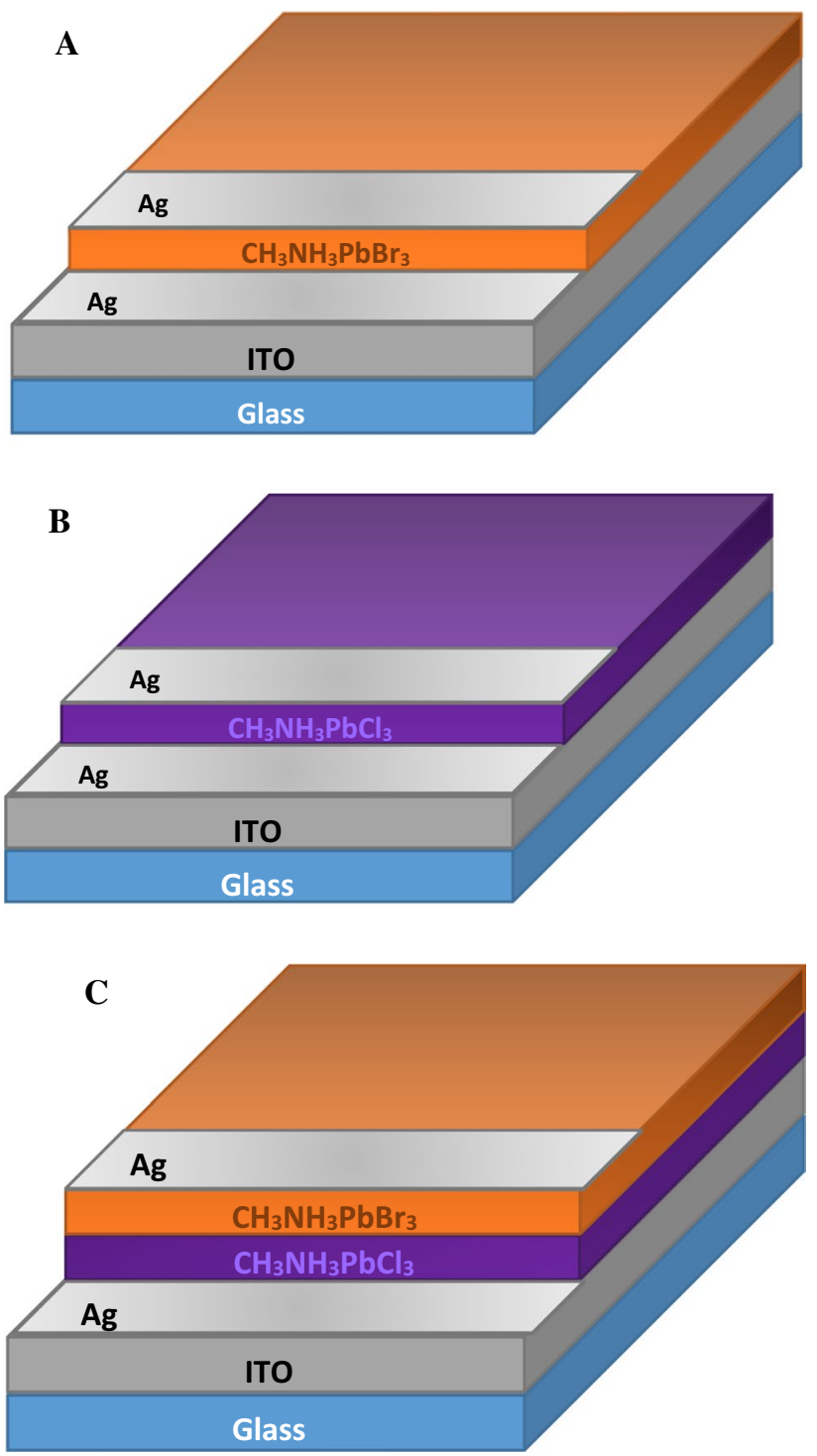

Fig. 1 Device schematic considered for PeLED based on a $\mathrm{CH}_{3} \mathrm{NH}_{3} \mathrm{PbBr}_{3}$ perovskite, b $\mathrm{CH}_{3} \mathrm{NH}_{3} \mathrm{PbCl}_{3}$ perovskite and c $\mathrm{CH}_{3} \mathrm{NH}_{3} \mathrm{PbCl}_{3} / \mathrm{CH}_{3} \mathrm{NH}_{3} \mathrm{PbBr}_{3}$ double perovskite

was stirred at $0{ }^{\circ} \mathrm{C}$ for $10 \mathrm{~min}$ to remove the heat of reaction. Thereupon, $2.492 \mathrm{~g}$ of lead bromide $\left(\mathrm{PbBr}_{2}\right.$, Sigma Aldrich) was added to the mix. The solution was sonicated for $15 \mathrm{~min}$ and put to dry in a watch glass for $24 \mathrm{~h}$, at room temperature. Afterward, the suspension was annealed at $60{ }^{\circ} \mathrm{C}$ for 1 week. Ultimately, the organic/inorganic perovskite $\left(\mathrm{CH}_{3} \mathrm{NH}_{3} \mathrm{PbBr}_{3}\right)$ was produced [34].

Synthesis of $\mathrm{CH}_{3} \mathrm{NH}_{3} \mathrm{PbCl}_{3}$ perovskite: the $\mathrm{CH}_{3} \mathrm{NH}_{3} \mathrm{Cl}$ was synthesized due to the reaction of $1.536 \mathrm{~mL}$ of hydrochloric acid fuming ( $\mathrm{HCl}, 37 \%$ extra pure, Merck) and $1.175 \mathrm{~mL}$ of methylamine $\left(\mathrm{CH}_{3} \mathrm{NH}_{2}, 40 \%\right.$ solution in water, Merck) in a $250-\mathrm{mL}$ round-bottom flask, for $10 \mathrm{~min}$ at $0{ }^{\circ} \mathrm{C}$ (to remove the heat of reaction) while stirring. Afterward, $2.492 \mathrm{~g}$ of lead (II) chloride ( $\mathrm{PbCl}_{2}$, Merck-Schuchardt) was 
added to the mixture and let to dry at room temperature in a watch glass for $24 \mathrm{~h}$. Again, the mixture was annealed at $60{ }^{\circ} \mathrm{C}$ for a week. The product of this process was organic/ inorganic perovskite $\left(\mathrm{CH}_{3} \mathrm{NH}_{3} \mathrm{PbCl}_{3}\right)$.

$\mathrm{CH}_{3} \mathrm{NH}_{3} \mathrm{PbBr}_{3}$ perovskite thin-film fabrication: ITOcoated glass substrate was sonicated four times in soap water, distilled water, ethanol, and acetone, each for $20 \mathrm{~min}$ and dried in the oven. $\mathrm{Next}, \mathrm{CH}_{3} \mathrm{NH}_{3} \mathrm{PbBr}_{3}$ perovskite was coated on the substrate by electron beam evaporation technique at a base pressure of $10^{-5}$ Torr [35].

$\mathrm{CH}_{3} \mathrm{NH}_{3} \mathrm{PbCl}_{3}$ perovskite thin-film fabrication: this perovskite thin film was fabricated with the same technique as $\mathrm{CH}_{3} \mathrm{NH}_{3} \mathrm{PbBr}_{3}$ perovskite thin film.

$\mathrm{CH}_{3} \mathrm{NH}_{3} \mathrm{PbCl}_{3} / \mathrm{CH}_{3} \mathrm{NH}_{3} \mathrm{PbBr}_{3}$ double-perovskite thinfilm fabrication: ITO-coated glass substrate was cleaned thoroughly, as reported above. Next, $\mathrm{CH}_{3} \mathrm{NH}_{3} \mathrm{PbCl}_{3}$ perovskite was coated on the substrate by electron beam evaporation technique at a base pressure of $10^{-5}$ Torr. After $72 \mathrm{~h}$, a layer of $\mathrm{CH}_{3} \mathrm{NH}_{3} \mathrm{PbBr}_{3}$ perovskite was coated on the prepared $\mathrm{CH}_{3} \mathrm{NH}_{3} \mathrm{PbCl}_{3}$ thin film via e-beam technique under the same conditions.

\section{Characterization techniques}

The structure and Bragg reflections of $\mathrm{CH}_{3} \mathrm{NH}_{3} \mathrm{PbX}$ $(\mathrm{X}=\mathrm{Br}, \mathrm{Cl})$ hybrids were characterized by $\mathrm{X}$-ray diffraction (XRD) $(\mathrm{Cu} \mathrm{K} \alpha \mathrm{X}$-ray radiation source) at $2 \theta$ within the angle range of 2 to $70^{\circ}$, by PANalytical model X'Pert Pro MPD. The scanning speed and step interval are $1 \% \mathrm{~min}$ and $0.02^{\circ}$, respectively. UV-visible optical absorption and emission spectra of perovskite thin film were measured using (Shimadzu UV-2450) spectrophotometer, in the range of 200-800 nm, and (JASCO FP-6200) spectrofluorometer at room temperature, respectively. Scanning electron microscopy (SEM) (LEO 1430VP) was used to determine the morphology of organic-inorganic perovskite thin films.

\section{Results and discussion}

The X-ray diffraction (XRD) patterns of $\mathrm{CH}_{3} \mathrm{NH}_{3} \mathrm{PbBr}_{3}$ and $\mathrm{CH}_{3} \mathrm{NH}_{3} \mathrm{PbCl}_{3}$ perovskite thin films and $\mathrm{CH}_{3} \mathrm{NH}_{3} \mathrm{PbCl}_{3} /$ $\mathrm{CH}_{3} \mathrm{NH}_{3} \mathrm{PbBr}_{3}$ bilayer perovskite thin film are presented in Fig. 2. To avoid the possible interferences in the XRD pattern, glass substrate was used instead of quartz substrate. The XRD pattern of $\mathrm{CH}_{3} \mathrm{NH}_{3} \mathrm{PbBr}_{3}$ perovskite thin film (Fig. 2a) presents keen peaks at $14.77^{\circ}, 20.97^{\circ}, 29.95^{\circ}, 33.8^{\circ}, 42.9^{\circ}$, $45.74^{\circ}$, which correlate well with $\langle 100\rangle,\langle 110\rangle,\langle 200\rangle$, $<210>,<220>$ and $<300>$ planes, respectively [35]. The sharp peaks shown in XRD pattern of $\mathrm{CH}_{3} \mathrm{NH}_{3} \mathrm{PbCl}_{3}$ perovskite thin film (Fig. 2b) correspond with $\langle 100\rangle,\langle 110\rangle$, $<111>,<200\rangle,<210\rangle,<211\rangle,<220\rangle,<300\rangle,<222\rangle$ and $<321>$ planes, respectively. These results are in accord

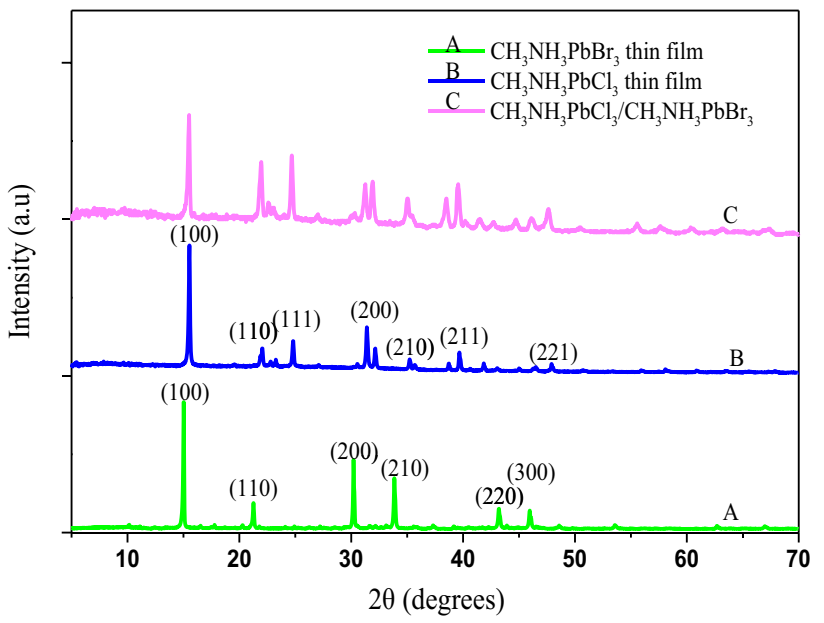

Fig. 2 X-ray diffraction pattern for a $\mathrm{CH}_{3} \mathrm{NH}_{3} \mathrm{PbBr}_{3}$ perovskite thin film, b $\mathrm{CH}_{3} \mathrm{NH}_{3} \mathrm{PbCl}_{3}$ perovskite thin film and c $\mathrm{CH}_{3} \mathrm{NH}_{3} \mathrm{PbCl}_{3}$ / $\mathrm{CH}_{3} \mathrm{NH}_{3} \mathrm{PbBr}_{3}$ double-perovskite thin film

with other similar reports [36]. Also, the XRD pattern of $\mathrm{CH}_{3} \mathrm{NH}_{3} \mathrm{PbCl}_{3} / \mathrm{CH}_{3} \mathrm{NH}_{3} \mathrm{PbBr}_{3}$ bilayer perovskite thin film is presented in Fig. 2c, and it confirms that $\mathrm{CH}_{3} \mathrm{NH}_{3} \mathrm{PbCl}_{3} /$ $\mathrm{CH}_{3} \mathrm{NH}_{3} \mathrm{PbBr}_{3}$ crystals are well fabricated and highly oriented with $\alpha$-axis self-assembly.

The UV-visible absorption spectra of $\mathrm{CH}_{3} \mathrm{NH}_{3} \mathrm{PbBr}_{3}$ (A: blue line) and $\mathrm{CH}_{3} \mathrm{NH}_{3} \mathrm{PbCl}_{3}$ (B: red line) perovskite thin films, at room temperature, show that the exciton absorption is located at $\sim 522 \mathrm{~nm}$ and $\sim 405 \mathrm{~nm}$, respectively (Fig. 3a). The UV-visible absorption spectrum of $\mathrm{CH}_{3} \mathrm{NH}_{3} \mathrm{PbCl}_{3}$ / $\mathrm{CH}_{3} \mathrm{NH}_{3} \mathrm{PbBr}_{3}$ double perovskite thin film is also shown in Fig. 3b.

The PL spectrum of $\mathrm{CH}_{3} \mathrm{NH}_{3} \mathrm{PbBr}_{3}$ perovskite thin film, at room temperature, at various excitation wavelengths indicates that the high emission intensity happens at excitation wavelength of $370 \mathrm{~nm}$ (Fig. 4a). According to the absorption spectrum of this thin film (Fig. 3), absorption at the wavelength of $370 \mathrm{~nm}$ is more intense than $420 \mathrm{~nm}$; hence, the number of electron-holes at $370 \mathrm{~nm}$ is much more than $420 \mathrm{~nm}$. Thus, more recombination at this wavelength is possible. The $\mathrm{PL}$ spectrum of $\mathrm{CH}_{3} \mathrm{NH}_{3} \mathrm{PbCl}_{3}$ perovskite thin film at different excitation wavelengths presents that this perovskite has a high emission intensity at excitation wavelength of $390 \mathrm{~nm}$ (Fig. 4b). As expected, at lower wavelengths the energy level is high, so electrons and holes receive enough energy to move to upper level. Since the possibility of recombination is decreased, the emission intensity is reduced in turn. The PL spectrum of $\mathrm{CH}_{3} \mathrm{NH}_{3} \mathrm{PbCl}_{3} /$ $\mathrm{CH}_{3} \mathrm{NH}_{3} \mathrm{PbBr}_{3}$ bilayer perovskite thin film shows that the high emission intensity is at the excitation wavelength of $390 \mathrm{~nm}$ (Fig. 4c).

Figure 5 shows the normalized photoluminescence (PL) spectra of thin perovskite films of $\mathrm{CH}_{3} \mathrm{NH}_{3} \mathrm{PbBr}_{3}$, 

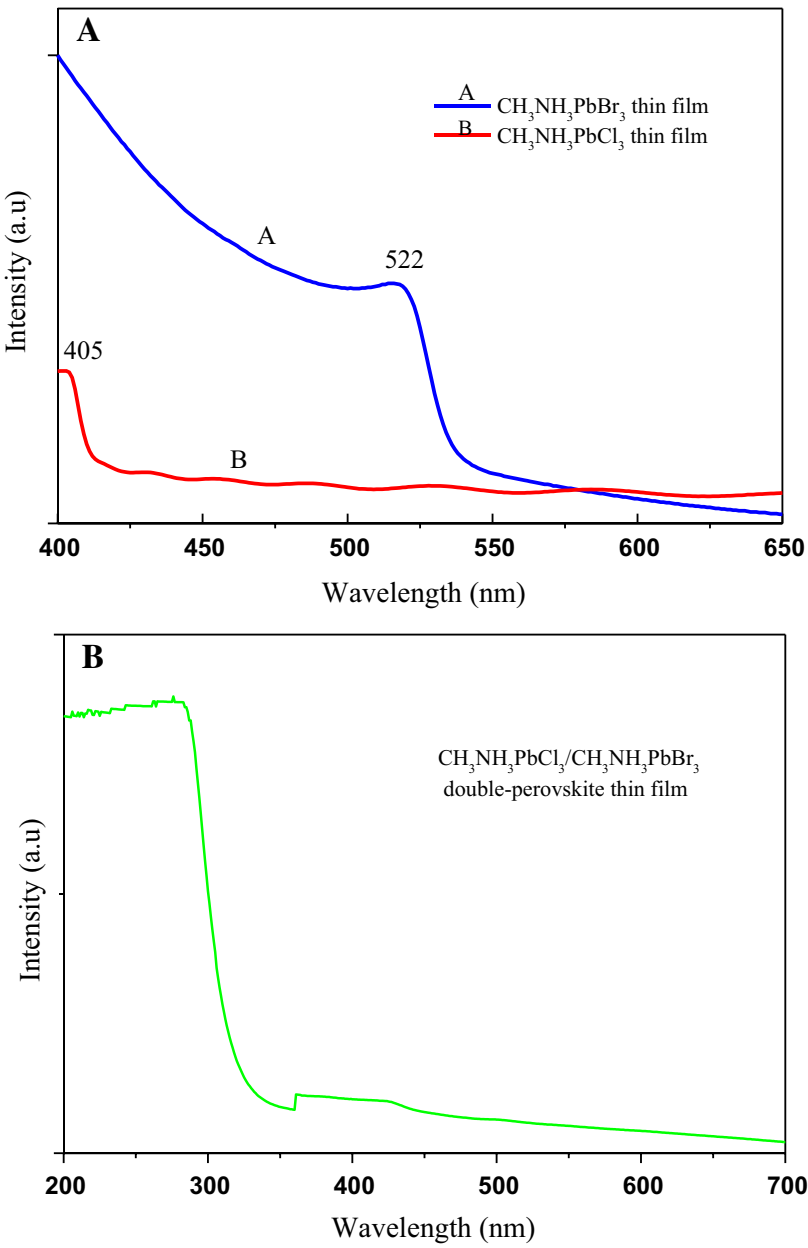

Fig. 3 a UV-visible absorption spectra of $\mathrm{CH}_{3} \mathrm{NH}_{3} \mathrm{PbBr}_{3}$ perovskite (A: blue line), $\mathrm{CH}_{3} \mathrm{NH}_{3} \mathrm{PbCl}_{3}$ perovskite (B: red line) and $\mathbf{b} \mathrm{UV}$-visible absorption spectra of $\mathrm{CH}_{3} \mathrm{NH}_{3} \mathrm{PbCl}_{3} / \mathrm{CH}_{3} \mathrm{NH}_{3} \mathrm{PbBr}_{3}$ double-perovskite thin film

$\mathrm{CH}_{3} \mathrm{NH}_{3} \mathrm{PbCl}_{3}$ and $\mathrm{CH}_{3} \mathrm{NH}_{3} \mathrm{PbCl}_{3} / \mathrm{CH}_{3} \mathrm{NH}_{3} \mathrm{PbBr}_{3}$ bilayer perovskite thin film, at room temperature, at $\lambda_{\mathrm{ex}}=390 \mathrm{~nm}$. As expected, the PL peaks' position shifts to shorter wavelengths (green to blue), through replacing $\mathrm{Br}$ with $\mathrm{Cl}$. In order to fabricate PeLEDs, we need to introduce charge injection/transport layers, adjacent to these semiconductor films. Therefore, we studied the PL wavelength of perovskites due to the presence of double layer of perovskite thin films. It can be seen that the emission band of $\mathrm{CH}_{3} \mathrm{NH}_{3} \mathrm{PbCl}_{3} / \mathrm{CH}_{3} \mathrm{NH}_{3} \mathrm{PbBr}_{3}$ bilayer perovskite thin films is in between the emission band of $\mathrm{CH}_{3} \mathrm{NH}_{3} \mathrm{PbBr}_{3}$ and $\mathrm{CH}_{3} \mathrm{NH}_{3} \mathrm{PbCl}_{3}$ perovskites.

SEM micrographs of the $\mathrm{CH}_{3} \mathrm{NH}_{3} \mathrm{PbBr}_{3}$ hybrid and thin film of $\mathrm{CH}_{3} \mathrm{NH}_{3} \mathrm{PbBr}_{3}$ hybrids are shown in Fig. 6a and b. Figure $6 \mathrm{a}$ shows that nanoparticles are formed without agglomeration. To investigate further, extracted histogram from SEM micrograph for the size distributions of hybrids shows that the mean diameter of halide perovskite is around
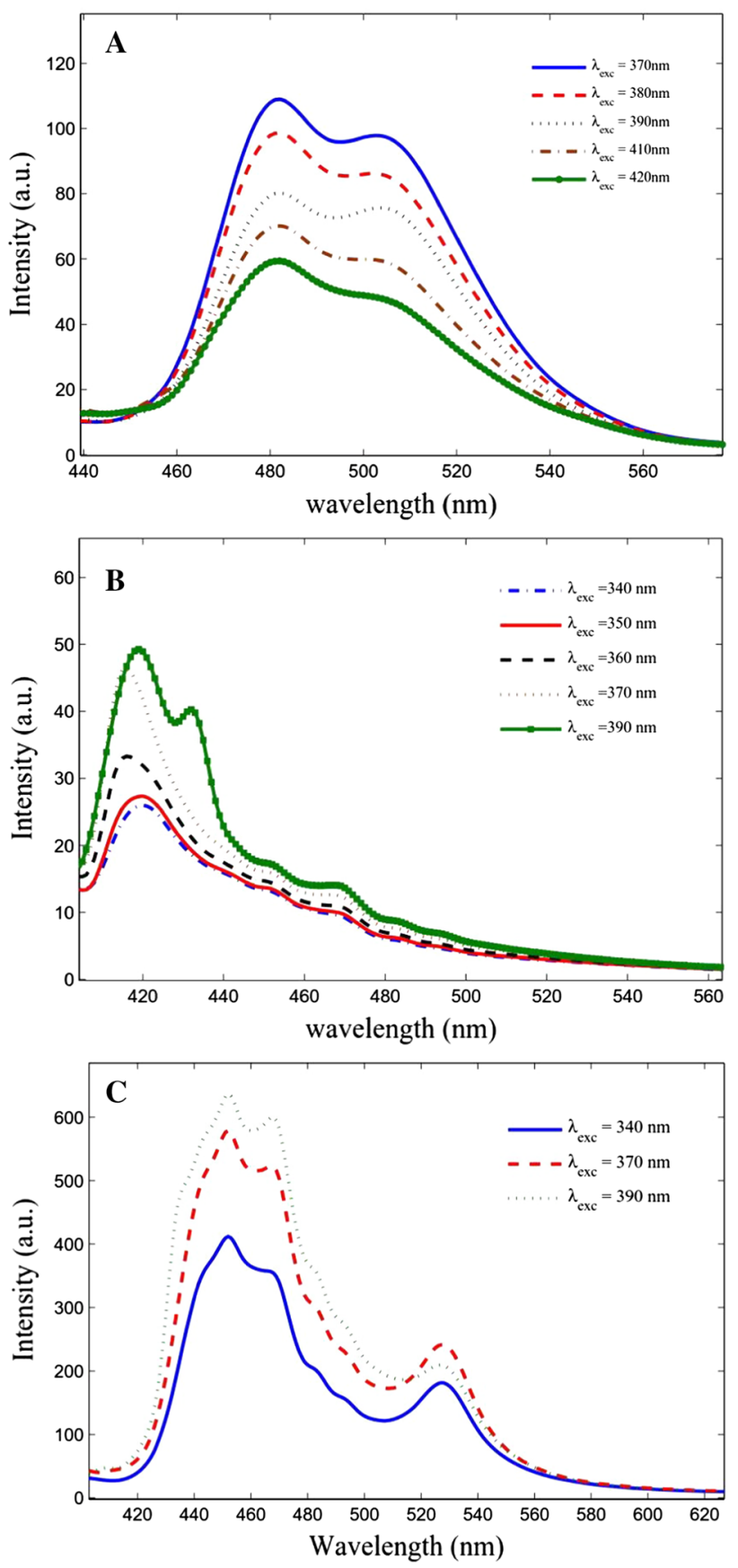

Fig. 4 Photoluminescence spectra of thin film of $\mathbf{a} \mathrm{CH}_{3} \mathrm{NH}_{3} \mathrm{PbBr}_{3}$ b $\mathrm{CH}_{3} \mathrm{NH}_{3} \mathrm{PbCl}_{3}$ and $\mathbf{c} \mathrm{CH}_{3} \mathrm{NH}_{3} \mathrm{PbCl}_{3} / \mathrm{CH}_{3} \mathrm{NH}_{3} \mathrm{PbBr}_{3}$ double perovskite fabricated by electron beam method

$57 \mathrm{~nm}$. Moreover, SEM micrograph of the thin films of $\mathrm{CH}_{3} \mathrm{NH}_{3} \mathrm{PbBr}_{3}$ hybrids (Fig. 6b) shows that the perovskite material forms a connected network with uniform and homogeneous particles.

The EL spectra of PeLEDs are shown in Fig. 7, at several voltages, at room temperature. $\mathrm{CH}_{3} \mathrm{NH}_{3} \mathrm{PbBr}_{3}$ perovskite thin film has a high emission at the voltage of $18 \mathrm{~V}$ (Fig. 7a). EL spectrum of $\mathrm{CH}_{3} \mathrm{NH}_{3} \mathrm{PbCl}_{3}$ perovskite thin film 


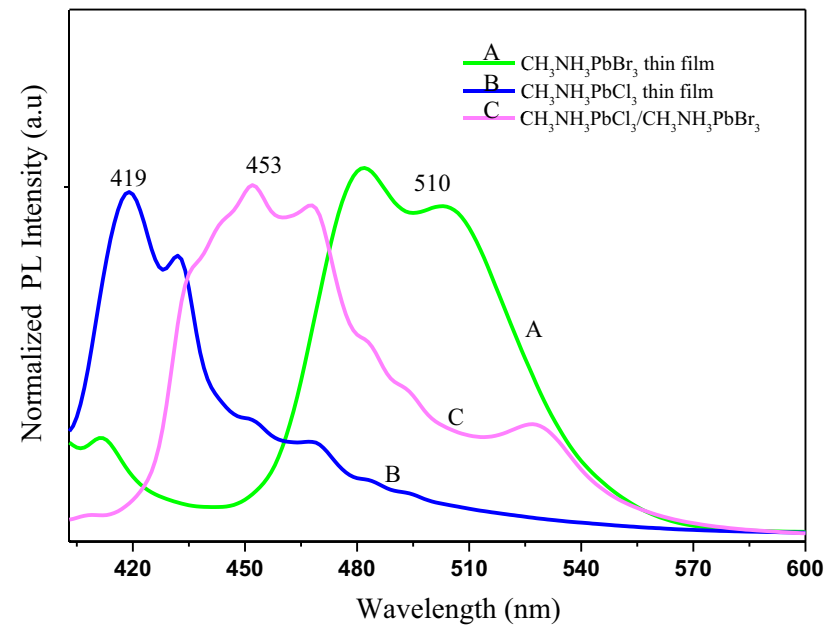

Fig. 5 Normalized Photoluminescence spectra of thin film of a $\mathrm{CH}_{3} \mathrm{NH}_{3} \mathrm{PbBr}_{3}$, b $\mathrm{CH}_{3} \mathrm{NH}_{3} \mathrm{PbCl}_{3}$ and $\mathbf{c} \mathrm{CH}_{3} \mathrm{NH}_{3} \mathrm{PbCl}_{3} / \mathrm{CH}_{3} \mathrm{NH}_{3} \mathrm{PbBr}_{3}$ double perovskite at $\lambda_{\mathrm{ex}}=390 \mathrm{~nm}$

has a green peak at 520-540 nm, at $18 \mathrm{~V}$ (Fig. 7b). Figure 7c presents the sharp peak for EL spectrum of $\mathrm{CH}_{3} \mathrm{NH}_{3} \mathrm{PbCl}_{3}$ / $\mathrm{CH}_{3} \mathrm{NH}_{3} \mathrm{PbBr}_{3}$ bilayer perovskite thin film at $550-575 \mathrm{~nm}$, at the voltage of $15 \mathrm{~V}$. Using these structures of perovskite and bilayer perovskite thin films, green light can be created. This double PeLEDs display a strong green electroluminescence at $556 \mathrm{~nm}$ and a high color purity with a narrow full width at half-maximum (FWHM) of $8.5 \mathrm{~nm}$. In Figs. 7 and 8 , we demonstrate the ability to tune the bandgap and emission wavelength of LEDs based on different halide, organic-inorganic perovskite films, which were measured at room temperatures. The EL emission wavelength monotonically changes from $530 \mathrm{~nm}$ for $\mathrm{CH}_{3} \mathrm{NH}_{3} \mathrm{PbCl}_{3}$-based LED to $556 \mathrm{~nm}$ for bilayer perovskite $\mathrm{CH}_{3} \mathrm{NH}_{3} \mathrm{PbCl}_{3} / \mathrm{CH}_{3} \mathrm{NH}_{3} \mathrm{PbBr}_{3}$ based LED. One notable observation is the narrow $8.5 \mathrm{~nm}$ EL FWHM for the $\mathrm{CH}_{3} \mathrm{NH}_{3} \mathrm{PbCl}_{3} / \mathrm{CH}_{3} \mathrm{NH}_{3} \mathrm{PbBr}_{3}$ bilayer perovskite-based LED, which to our knowledge is one of the lowest FWHM observed for any solution processed material, at room temperature, to this date.
The phenomenal performance of hybrid perovskites arises from the substantial characteristic properties they possess. Studies on the electronic structures of perovskites have shown that the electronic states are affected by substituting the halide component, such that a valence band transition from $3 p \rightarrow 4 p \rightarrow 5 p$ occurs for substitutions $\mathrm{Cl} \rightarrow \mathrm{Br} \rightarrow \mathrm{I}$. Accordingly, this lowers the ionization potential (binding energy) [37]. Furthermore, the energy level diagram of the devices is shown in Fig. 8. Electrons and holes are injected from the cathode (Al) and the anode (ITO), respectively. So, carriers' recombination, excitons formation and emission occur in the thin film of perovskites.

The current versus voltage curves for $\mathrm{CH}_{3} \mathrm{NH}_{3} \mathrm{PbBr}_{3}$, $\mathrm{CH}_{3} \mathrm{NH}_{3} \mathrm{PbCl}_{3}$ perovskite thin films and $\mathrm{CH}_{3} \mathrm{NH}_{3} \mathrm{PbCl}_{3} /$ $\mathrm{CH}_{3} \mathrm{NH}_{3} \mathrm{PbBr}_{3}$ bilayer perovskite thin film (Fig. 9) reveal that these thin films behave like LED. All three of diodes show reasonably good diode characteristics with their knee voltages in the range of $\sim 1 \mathrm{~V}$. Also, the current-voltage diagram for the light-emitting diodes in Fig. 9 indicates that for a light-emitting diode fabricated by a double layer perovskite thin films the threshold voltage for light emission is about 7 volts, and this voltage is higher than the threshold voltage for $\mathrm{CH}_{3} \mathrm{NH}_{3} \mathrm{PbBr}_{3}$ and $\mathrm{CH}_{3} \mathrm{NH}_{3} \mathrm{PbCl}_{3}$ structures.

\section{Conclusion}

In summary, we expanded a modern construction method that permits PeLED devices to be created easily in ambient condition. Moreover, we illustrated multicolor organic/inorganic hybrid PeLED, using $\mathrm{CH}_{3} \mathrm{NH}_{3} \mathrm{PbCl}_{3} /$ $\mathrm{CH}_{3} \mathrm{NH}_{3} \mathrm{PbBr}_{3}$ bilayer perovskite thin film as EML. We detected a very peculiar set of specifications for organic/inorganic hybrid perovskites $\mathrm{CH}_{3} \mathrm{NH}_{3} \mathrm{PbBr}_{3}$ and $\mathrm{CH}_{3} \mathrm{NH}_{3} \mathrm{PbCl}_{3}$ that display phenomenal semiconducting behavior and exhibit superior PV performance. The wonderful optical properties of these three dimensional organic/inorganic materials show their potential to be utilized in light-emitting devices. We found that our new structure used as the active layer, presented
Fig. 6 SEM micrographs of the a $\mathrm{CH}_{3} \mathrm{NH}_{3} \mathrm{PbBr}_{3}$ hybrid and b thin film of $\mathrm{CH}_{3} \mathrm{NH}_{3} \mathrm{PbBr}_{3}$ hybrids
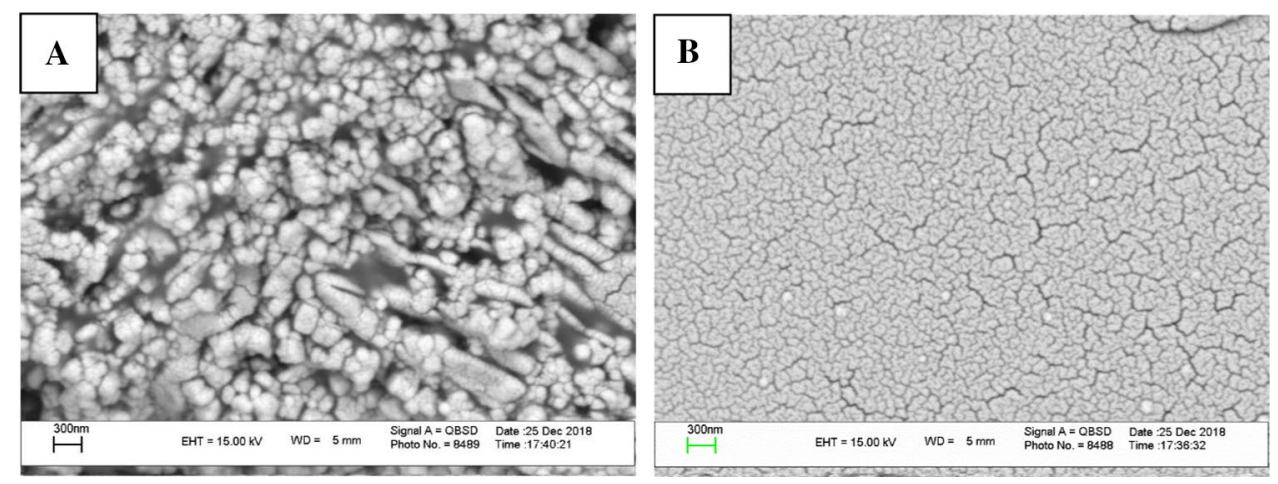

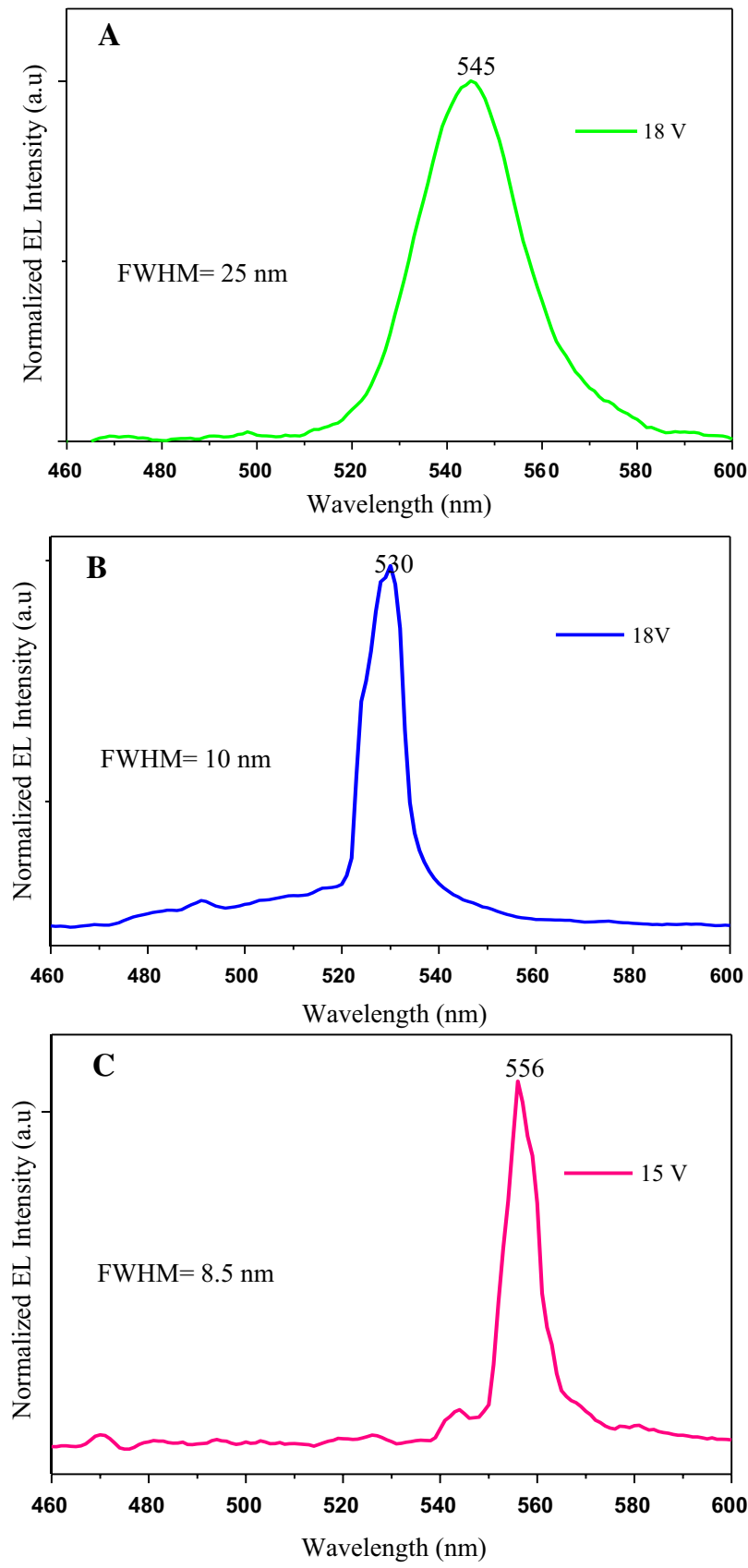

Fig. 7 Electroluminescence spectrum of a $\mathrm{CH}_{3} \mathrm{NH}_{3} \mathrm{PbBr}_{3}$ perovskite b $\mathrm{CH}_{3} \mathrm{NH}_{3} \mathrm{PbCl}_{3}$ perovskite $\mathbf{c}$ and $\mathrm{CH}_{3} \mathrm{NH}_{3} \mathrm{PbCl}_{3} / \mathrm{CH}_{3} \mathrm{NH}_{3} \mathrm{PbBr}_{3}$ double-perovskite-based LEDs

several advantages. The electron injection barrier with the perovskite could be reduced using bilayer perovskite thin film as EML, which decreases the electron affinity relative to the vacuum level and reduces the PeLEDs' turn-on voltage. The full width half maximum (FWHM) of the electroluminescence peak from $\mathrm{CH}_{3} \mathrm{NH}_{3} \mathrm{PbCl}_{3} /$ $\mathrm{CH}_{3} \mathrm{NH}_{3} \mathrm{PbBr}_{3}$ bilayer perovskite is $8.5 \mathrm{~nm}$, which is a quarter of the FWHM from industry standard green
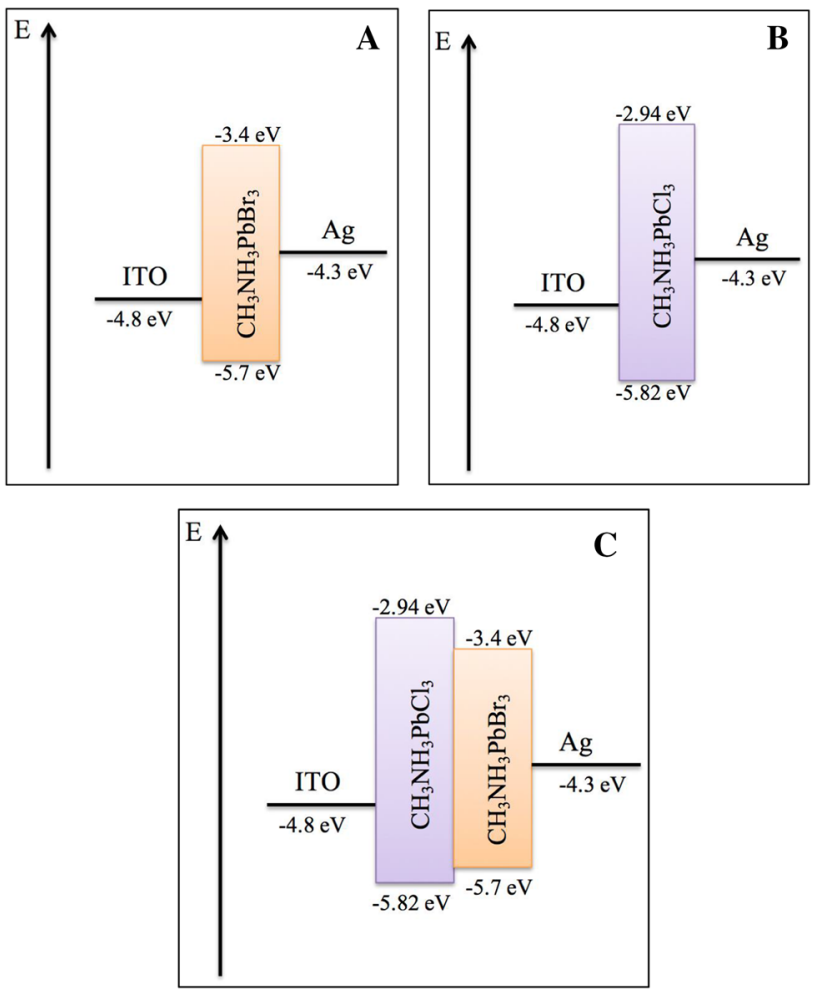

Fig. 8 Energy level diagram of the devices with a $\mathrm{CH}_{3} \mathrm{NH}_{3} \mathrm{PbBr}_{3}$ perovskite b $\mathrm{CH}_{3} \mathrm{NH}_{3} \mathrm{PbCl}_{3}$ perovskite and c $\mathrm{CH}_{3} \mathrm{NH}_{3} \mathrm{PbCl}_{3} /$ $\mathrm{CH}_{3} \mathrm{NH}_{3} \mathrm{PbBr}_{3}$ double perovskite as an active layer

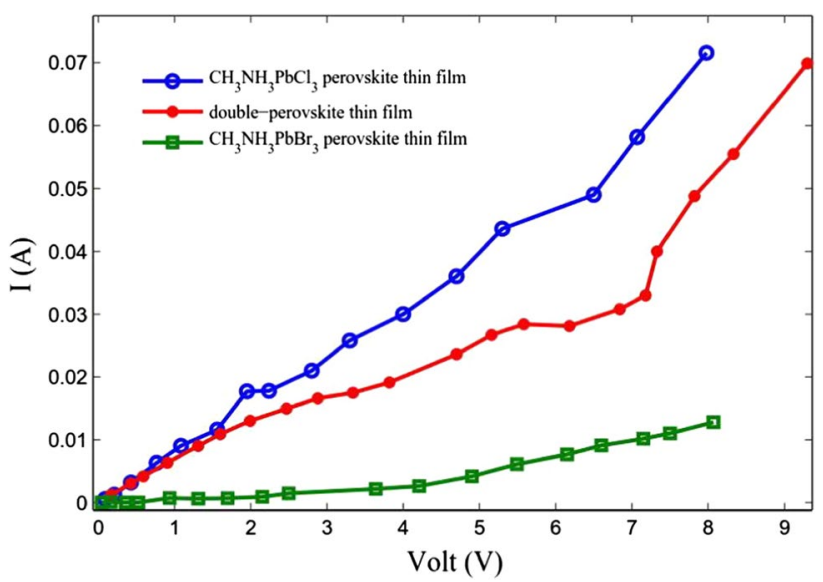

Fig. $9 \mathrm{I}-\mathrm{V}$ characteristic of a $\mathrm{CH}_{3} \mathrm{NH}_{3} \mathrm{PbBr}_{3}$ perovskite b $\mathrm{CH}_{3} \mathrm{NH}_{3} \mathrm{PbCl}_{3}$ perovskite and $\mathbf{c} \mathrm{CH}_{3} \mathrm{NH}_{3} \mathrm{PbCl}_{3} / \mathrm{CH}_{3} \mathrm{NH}_{3} \mathrm{PbBr}_{3}$ double-perovskite-based LEDs

InGaN LEDs [38], and less than half the FWHM of the peak from the $\mathrm{CH}_{3} \mathrm{NH}_{3} \mathrm{PbBr}_{3}$ PLED (Fig. 6a, d), at room temperature. Application of organometal halide perovskites in LEDs is currently in its outset, but if their 
development in the field of solar cells can be taken as an example, these materials promise surplus discoveries that will lead to rapid efficiency developments.

Open Access This article is distributed under the terms of the Creative Commons Attribution 4.0 International License (http://creativeco mmons.org/licenses/by/4.0/), which permits unrestricted use, distribution, and reproduction in any medium, provided you give appropriate credit to the original author(s) and the source, provide a link to the Creative Commons license, and indicate if changes were made.

\section{References}

1. Qin, X., Dong, H., Hu, W.: Green light-emitting diode from bromine based organic-inorganic halide perovskite. J. Sci. China Mater. 58, 186-191 (2015)

2. Kazim, S., Nazeeruddin, M.K., Gratzel, M., Ahmad, S.: Perovskite as light harvester: a game changer in photovoltaics. J. Angew. Chem. 53, 2812-2824 (2014)

3. Hatamvand, M., Mirjalili, S.A., Sharzehee, M., Behjat, A., Jabbari, M., Skrifvars, M.: Fabrication parameters of low-temperature $\mathrm{ZnO}$-based hole-transport-free perovskite solar cells. Optik 140, 443-450 (2017)

4. Jeon, N.J., Noh, J.H., Yang, W., Kim, Y.C., Ryu, S., Seo, J., Seok, S.: Compositional engineering of perovskite materials for highperformance solar cells. Nature 517, 476-480 (2014)

5. Hong, S., Han, A., Lee, E.C., Ka, K.W., Park, J., Song, H., Han, M., Han, C.: A facile and low-cost fabrication of $\mathrm{TiO}_{2}$ compact layer for efficient perovskite solar cells. Curr. Appl. Phys. 15, 574-579 (2015)

6. Kim, Y.H., Cho, H., Heo, J., Kim, T., Myouung, N., Lee, C.L., Im, S., Lee, T.W.: Multicolores organic/inorganic hybrid perovskite light-emitting diodes. J. Adv. Mater. 27, 1248-1254 (2015)

7. Li, X., Li, L., Ma, Z., Huang, J., Ren, F.: Low-cost synthesis, fluorescent properties, growth mechanism and structure of $\mathrm{CH}_{3} \mathrm{NH}_{3} \mathrm{PbI}_{3}$ with millimeter grains. Optik 142, 293-300 (2017)

8. Stoumpos, C.C., Malliakas, C.D., Kanatzidis, M.G.: Semiconducting tin and lead iodide perovskites with organic cations: phase transitions, high mobilities, and near-infrared photoluminescent properties. J. Inorg. Chem. 52, 9019-9038 (2013)

9. Noh, J.H., Im, S.H., Heo, J.H., Mandal, T.N., Seok, S.: Chemical management for colorful, efficient, and stable inorganic-organic hybrid nanostructured solar cells. Nano Lett. 13, 1764-1769 (2013)

10. Burschka, J., Pellet, N., Moon, S.J., Baker, R.H., Gao, P., Nazeeruddin, M.K., Gratzel, M.: Sequential deposition as a route to high-performance perovskite-sensitized solar cells. Nature 499, 316-319 (2013)

11. Xing, G., Mathews, N., Lim, S.S., Yantara, N., Liu, X., Sabba, D., Gratzel, M., Mhaisalkar, S., Sum, T.C.: Low-temperature solutionprocessed wavelength-tunable perovskites for lasing. Nat. Mater. 13, 476-480 (2013)

12. Sutherland, B.R., Hoogland, S., Adachi, M.M., Kanjanaboos, P., Wong, C.T., McDowell, J.J., Xu, J., Voznyy, O., Ning, Z., Houtepen, A.J., Sargent, E.H.: Perovskite thin film via atomic layer deposition. J. Adv. Mater. 27, 53-58 (2015)

13. Kim, Y.H., Cho, H., Heo, J.H., Im, S.H., Lee, T.W.: Effects of thermal treatment on organic-inorganic hybrid perovskite films and luminous efficiency of light-emitting diodes. Curr. Appl. Phys. 16, 1069-1074470 (2016)

14. Zhou, H., Chen, Q., Li, G., Luo, S., Song, T., Duan, H., Hong, Z., You, J., Liu, Y., Yang, Y.: Interface engineering of highly efficient perovskite solar cells. Science 345, 542-546 (2014)
15. Zhang, Q., Ha, S.T., Liu, X., Sum, T.C., Xiong, Q.: Room-temperature near-infrared high-Q perovskite whispering-gallery planar nanolasers. Nano Lett. 14, 5995-6001 (2014)

16. Ha, S.T., Liu, X., Zhang, Q., Giovanni, D., Sum, T.C., Xiong, Q.: Synthesis of organic-inorganic lead halide perovskite nanoplatelets: towards high-performance perovskite solar cells and optoelectronic devices. Adv. Opt. Mater. 2, 838-844 (2014)

17. Wehrenfennig, C., Liu, M., Snaith, H.J., Johnston, M.B., Herz, L.M.: Homogeneous emission line broadening in the organo lead halide perovskite $\mathrm{CH}_{3} \mathrm{NH}_{3} \mathrm{PbI}_{3-\mathrm{x}} \mathrm{Cl}_{\mathrm{X}}$. J. Phys. Chem. Lett. 5, 1300-1306 (2014)

18. Zhu, L., Xiao, J., Shi, J., Wang, J., Lv, S., Xu, Y., Luo, Y., Xiao, Y., Wang, Sh: Efficient $\mathrm{CH}_{3} \mathrm{NH}_{3} \mathrm{PbI}_{3}$ perovskite solar cells with 2TPA-n-DP hole-transporting layers. J. Nano Res. 8, 1116-1127 (2014)

19. Ban, M., Zou, Y., Rivett, J.P.H., Yang, Y., Thomas, T.H., Tan, Y., Song, T., Gao, X., Credington, D., Deschler, F., Sirringhaus, H., Sun, B.: Solution-processed perovskite light emitting diodes with efficiency exceeding $15 \%$ through additive-controlled nanostructure tailoring. Nat. Commun. 9, 3892 (2018)

20. Zhao, L.R., Lee, K.M., Roh, K., Khan, S.U.Z., Rand, B.P.: Improved outcoupling efficiency and stability of perovskite light-emitting diodes using thin emitting layers. Adv. Mater. 31, 1805836 (2019)

21. Shi, X.B., Liu, Y., Yuan, Z., Liu, X.K., Miao, Y., Wang, J., Lenk, S., Reineke, S., Gao, F.: Optical energy losses in organic-inorganic hybrid perovskite light-emitting diodes. Adv. Opt. Mater. 6, 1800667 (2018)

22. Yan, F., Xing, J., Xing, G., Quan, L., Tan, S.T., Zhao, J., Su, R., Zang, L., Chen, S., Zhao, Y., Huan, A., Sargent, E.H., Xiong, Q., Demir, H.V.: Highly efficient visible colloidal lead-halide perovskite nanocrystal light-emitting diodes. Nano Lett. 18, 3157-3164 (2018)

23. Stranks, S.D., Eperon, G.E., Grancini, G., Menelaou, C., Alcocer, M.J., Leijtens, T., Herz, L.M., Petrozza, A., Snaith, H.J.: Electronhole diffusion lengths exceeding 1 micrometer in an organometal trihalide perovskite absorber. Science 342, 341-344 (2013)

24. Xing, J., Yan, F., Zhao, Y., Chen, S., Yu, H., Zhang, Q., Zeng, R., Volkan, D.H., Sun, X., Huan, A., Xiong, Q.: High-efficiency light-emitting diodes of organometal halide perovskite amorphous nanoparticles. ACS Nano 10, 6623-6630 (2016)

25. Malinkiewicz, O., Roldan-Carmona, C., Soriano, A., Bandiello, E., Camacho, L., Nazeeruddin, M.K., Bolink, H.J.: Metal-oxidefree methylammonium lead iodide perovskite-based solar cells: the influence of organic charge transport layers. Adv. Energy Mater. 4, 1400345 (2014)

26. Priante, D., Dursun, I., Alias, M.S., Shi, D., Melnikov, V.A., Ng, T.K., Mohammed, O.F., Bakr, O.M., Ooi, B.S.: The recombination mechanisms leading to amplified spontaneous emission at the true green wavelength in $\mathrm{CH} 3 \mathrm{NH} 3 \mathrm{PbBr} 3$ perovskite. Appl. Phys. Lett. 106, 081902 (2015)

27. Tan, Z.K., Moghaddam, R.S., Lai, M.L., Docampo, P., Higler, R., Deschler, F., Price, M., Sadhanala, A., Pazos, L.M., Credgington, D., Hanusch, F., Bein, T., Snaith, H.J., Friend, R.H.: Bright light-emitting diodes based on organometal halide perovskite. Nat. Nanotechnol. 9, 687-692 (2014)

28. Kim, Y.H., Cho, H., Heo, J.H., Kim, T.S., Myoung, N., Lee, C.L., Im, S.H., Lee, T.W.: Multicolored organic/inorganic hybrid perovskite light-emitting diodes. J. Adv. Mater. 27, 1248-1254 (2014)

29. Gil-Escrig, L., Longo, G., Pertegas, A., Roldan-Carmona, C., Soriano, A., Sessolo, M., Bolink, H.J.: Efficient photovoltaic and electroluminescent perovskite devices. Chem. Commun. 51, 569-571 (2015)

30. Deschler, F., Price, M., Pathak, S., Klintberg, L.E., Jarausch, D.D., Higler, R., Huttner, S., Leijtens, T., Stranks, S.D., Snaith, H.J., 
Atature, M., Philips, R.T., Friend, R.H.: High photoluminescence efficiency and optically pumped lasing in solution-processed mixed halide perovskite semiconductor. J. Phys. Chem. Lett. 5, 1421-1426 (2014)

31. Mirershadi, S., Ahmadi-kandejani, S.: Efficient thin luminescent solar concentrator based on organometal halide perovskite. Dyes Pigm. 120, 15-21 (2015)

32. Chondroudis, K., Mitzi, D.B.: Electroluminescence from an organic-inorganic perovskite incorporating a quaterthiophene dye within lead halide perovskite layers. Chem. Mater. 11, 3028-3030 (1999)

33. Era, M., Morimoto, S., Tsutui, T., Saito, S.: Organic-inorganic heterostructure electroluminescent device using a layered perovskite semiconductor $\left(\mathrm{C}_{6} \mathrm{H}_{5} \mathrm{C}_{2} \mathrm{H}_{4} \mathrm{NH}_{3}\right)_{2} \mathrm{PbI}_{4}$. Appl. Phys. Lett. 65, 676 (1994)

34. Mirershadi, S., Ahmadi-Kandjani, S., Zakerhamidi, M.S., Mortazavi, S.Z.: Optical and structural effects due to the control of organic and inorganic composition percentage in $\mathrm{CH} 3 \mathrm{NH} 3 \mathrm{PbBr} 3$ perovskite. Iran. J. Sci. Technol. Trans. A Sci. 41, 873-881 (2017)

35. Mirershadi, S., Ahmadi-Kandejani, S., Zawadzka, A., Sahraoui, B.: Perovskite by means of the Z-scan technique. Chem. Phys. Lett. 647, 7-13 (2016)
36. Maculan, G., Sheikh, A.D., Abdelhady, A.L., Saidaminov, M.I., Haque, A., Murali, B., Alarousu, E., Mohammed, O.F., Wu, T., Bakr, O.M.: $\mathrm{CH}_{3} \mathrm{NH}_{3} \mathrm{PbCl}_{3}$ single crystals: inverse temperature crystallization and visible-blind UV-photodector. J. Phys. Chem. Lett. 6, 3781-3786 (2015)

37. Frost, J.M., Butler, K.T., Brivio, F., Hendon, C.H., Schilfgaarde, M., Walsh, A.: Atomistic origins of high-performance in hybrid halide perovskite solar cells. Nano Lett. 14(5), 2584-2590 (2014)

38. Bayram, C., Teherani, F.H., Rogers, D.J., Razeghi, M.: A hybrid green light-emitting diode comprised of $\mathrm{n}-\mathrm{ZnO} /(\mathrm{InGaN} / \mathrm{GaN})$ multi-quantum-wells/p-GaN. Appl. Phys. Lett. 93(8), 081111 (2008)

Publisher's Note Springer Nature remains neutral with regard to jurisdictional claims in published maps and institutional affiliations. 